Journal of Bangladesh Academy of Sciences, Vol. 38, No. 2, 103-110, 2014

\title{
EFFECTS OF TEMPERATURE ON SOME PHYSIOLOGICAL TRAITS OF WHEAT
}

FARIDA BEGUM ${ }^{1}$ AND ASHRATUN NESSA

Plant Physiology Division, Bangladesh Agricultural Research Institute, Joydebpur, Gazipur

\begin{abstract}
The effect of high temperature on some physiological traits of wheat has been studied under controlled condition in a green house. The temperature stress chosen for the study were $25 \pm 1 / 14 \pm$ $1{ }^{\circ} \mathrm{C}$ (control) $28 \pm 1 / 18 \pm 1{ }^{\circ} \mathrm{C}$ day/night and $35 \pm 1 / 25 \pm 1{ }^{\circ} \mathrm{C}$ day/night temperature. Total crop duration was reduced under higher temperature. The results showed that leaf dry weight, shoot dry weight, flag leaf area of wheat was reduced under higher temperature. High temperature brought sterility and consequently reduced grain yield. Wheat plant grown under $35 \pm 1 / 25 \pm 1{ }^{\circ} \mathrm{C}$, day night temperature failed to form any seed. Chlorophyll content also directly related to grain weight. High temperature reduced leaf chlorophyll content as well as grain weight.
\end{abstract}

Key words: Effects of temperature, Wheat, Chlorophyll content, Yield and Yield components

\section{INTRODUCTION}

Wheat is the second important cereal crop grown in Bangladesh. The optimum sowing time of wheat is 3rd week of November with favorable temperature. But due to late harvest of transplanted aman, farmers cannot grow wheat in optimum time. Late sowing of wheat ultimately results in exposure of plants to high temperature. Delayed sowing in wheat experiences high temperature which reduced the vegetative phase and shortening of grain growth duration force to attain lower partitioning of dry matter and reduction in yield than timely sown crop as observed by Mishra et al. (2003). High temperature $\left(<28^{\circ} \mathrm{C}\right)$ during grain development is the most important factor in yield reduction. This elevated temperature reduced the duration and ultimately caused lowering the grain yield (Wang et al. 1992). Wheat is called a winter crop because it is mostly grown in cool environment. Among the various climatic factors that affect growth and yield of wheat, temperature stress is the most critical. This temperature stress may prevail throughout the growing period of wheat or it may act as a terminal stress. Agronomists and physiologists have found that grain development of wheat is adversely affected if the average temperature exceeds $25^{\circ} \mathrm{C}$ (Tandon 1984). The effect of temperature stress on the above ground biomass production and grain yield has been studied. High temperature

${ }^{1}$ Seed Technology Division, BARI. 
stress imposed by delayed sowing is found to reduce yield indirectly through affecting various yield components. The present experiment was, therefore, carried out to observe the effect of temperature on some physiological traits that ultimately responsible for yield reduction due to delayed sowing.

\section{MATERIALS AND METHODS}

The experiment was conducted in the greenhouse at BARI, Joydebpur Gazipur during rabi season. Three cultivars of wheat viz., Shatabdi, Bijoy and Prodip were grown in plastic pots containing $12 \mathrm{~kg}$ of air dry soil. Recommended fertilizer dose of 80-60-40$20 \mathrm{~kg} \mathrm{~N}-\mathrm{P}_{2} \mathrm{O}_{5}-\mathrm{K}_{2} \mathrm{O}$ S/ha was applied. Total amount of TSP, MOP and 2/3rd of urea were incorporate in soil at the time of sowing. The rest $1 / 3 \mathrm{rd}$ of urea was applied at 3-leaf stage. Three treatments were imposed in this experiment. Treatments were (I) plants grown under $25 \pm 1 / 14^{\circ} \pm 1^{\circ} \mathrm{C}$ day/night temperature (control) (II) $28 \pm 1 / 18^{\circ} \mathrm{C} \pm 1$ day/night temperature and (III) $35 \pm 1 / 25^{\circ} \mathrm{C} \pm 1$ day/night temperature regime. Seeds were sown in plastic pots on 17 November. After seedling establishment, 5 plants were kept in each pot. Thirty days after sowing the plants were subjected to temperature stress. Ten pots of each variety were transfered to three different compartments of the green house maintaining desired temperature. According to agronomists and physiologists, grain development of wheat is adversely affected if the average temperature exceeds $25^{\circ} \mathrm{C}$ (Tandon 1984). So the treatment $25^{\circ} \pm 1 / 14^{\circ} \pm 1^{\circ} \mathrm{C}$ considered as control. Chlorophyll a, b and total chlorophyll content of the flag leaf were determined following Witham et al. (1971) at vegetative, booting and anthesis stage. Data on flag leaf area, dry weight of leaf, stem, yield and yield component were also recorded.

\section{RESULTS AND DISCUSSION}

Temperature has direct effect on crop duration. Higher temperature than the optimum generally shortens the duration. Crop growth duration did not vary among the tested varieties of wheat under $25^{\circ} \mathrm{C}$ condition. Wheat plant grown under $25^{\circ} \mathrm{C}$ took 98 99 days to complete its life cycle (Table 1). It was observed that under temperature stress condition the crop duration was reduced. Under control condition the crop duration were 99, 99 and 98 for Shatabdi, Bijoy and Prodip, respectively. Crop growth duration was reduced to 95,88 and 95 at $28^{\circ} \mathrm{C}$ and 81,76 and 81 at $35^{\circ} \mathrm{C}$ for Shatabdi, Bijoy and Prodip, respectively (Table 1). Among the three varieties the reduction of crop growth duration was maximum in Bijoy $\left(11\right.$ days at $28^{\circ} \mathrm{C}$ and 32 days at $35^{\circ} \mathrm{C}$ ) indicating that Bijoy is the most sensitive to high temperature stress for crop growth duration. Similar decrease in crop duration due to high temperature was also observed in barley (Roy and Nafgizer 1987). 
Table 1. Effects of temperatures on physiological maturity of wheat varieties.

\begin{tabular}{lccccc}
\hline \multirow{2}{*}{ Cultivars } & \multicolumn{2}{c}{$\begin{array}{c}\text { Physiological maturity } \\
\text { (Days) }\end{array}$} & \multicolumn{2}{c}{$\begin{array}{c}\text { Relative physiological maturity as } \\
\text { percentage of control (\%) }\end{array}$} \\
\cline { 2 - 6 } & Control & $28^{\circ} \mathrm{C}$ & $35^{\circ} \mathrm{C}$ & $28^{\circ} \mathrm{C}$ & $35^{\circ} \mathrm{C}$ \\
\hline Shatabdi & 99 & 95 & 81 & -4 & -18 \\
Bijoy & 99 & 88 & 76 & -11 & -23 \\
Prodip & 98 & 95 & 81 & -3 & -17 \\
\hline
\end{tabular}

Plant height is a varietal character. In the present experiment plant height was affected by temperature. Plant height and relative plant height as compared to control are presented in Table 2 and Fig. 1, respectively. Plant height of all the varieties increased with the advancement of growth up to 70 days after sowing and then declined. At harvest the highest plant height was observed in Shatabdi and Prodip under control condition $\left(25^{\circ} \mathrm{C}\right)$. At $35^{\circ} \mathrm{C}$, the plant height of Shatabdi and Prodip were reduced by 8 and $9 \%$, respectively. Plant height in tested varieties of wheat decreased with the increase in temperature but among these varieties the variety Bijoy showed lower relative plant height both at 28 and $35^{\circ} \mathrm{C}$ (Fig. 1).

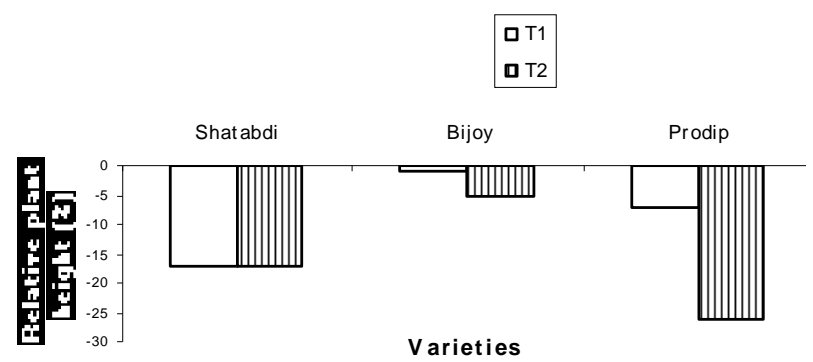

Fig. 1. Effects of temperature on relative plant height of wheat.

Campbel and Read (1968) observed a shorter plant height of wheat under higher temperature imposed by late sowing. The reduction in plant height under higher temperature is in agreement with the observation of Rao and Wattal (1986) in Barley.

Table 2. Effects of temperature on plant height $(\mathrm{cm})$ of wheat.

\begin{tabular}{lccccccccc}
\hline Cultivars & \multicolumn{3}{c}{$55 \mathrm{DAS}$} & \multicolumn{3}{c}{$70 \mathrm{DAS}$} & \multicolumn{3}{c}{ At harvest } \\
\hline & Control & $28^{\circ} \mathrm{C}$ & $35^{\circ} \mathrm{C}$ & Control & $28^{\circ} \mathrm{C}$ & $35^{\circ} \mathrm{C}$ & Control & $28^{\circ} \mathrm{C}$ & $35^{\circ} \mathrm{C}$ \\
Shatabdi & $74 \pm 1$ & $66 \pm 2$ & $63 \pm 3$ & $86 \pm 3$ & $73 \pm 3$ & $65 \pm 2$ & $84 \pm 1$ & $70 \pm 4$ & $57 \pm 3$ \\
Bijoy & $82 \pm 2$ & $66 \pm 7$ & $66 \pm 7$ & $85 \pm 2$ & $83 \pm 2$ & $65 \pm 4$ & $82 \pm 2$ & $81 \pm 1$ & $78 \pm 1$ \\
Prodip & $81 \pm 2$ & $66 \pm 2$ & $66 \pm 2$ & $85 \pm 4$ & $68 \pm 6$ & $65 \pm 3$ & $84 \pm 1$ & $78 \pm 2$ & $62 \pm 2$ \\
\hline
\end{tabular}

Leaf area is one of the best measures of a crop capacity to produce dry matter and grain yield as well (Gardner 1985). In case of cereal crops like rice, wheat, barley, oat etc. flag leaf area is an important component related to yield. A positive correlation 
between wheat flag leaf area and yield was noted by Simon (1999). In the present experiment the flag leaf length of Shatabdi, Bijoy and Prodip were 18, 15.93 and $19.5 \mathrm{~cm}$ under control condition (Table 3). At $35^{\circ} \mathrm{C}$, flag leaf length was reduced and it was 17.2, 11.87 and $13.43 \mathrm{~cm}$ for Shatabdi, Bijoy and Prodip respectively. However, Shatabdi showed highest relative flag leaf length as compared to control under temperature stress. Flag leaf area followed the same trend as flag leaf length in all the varieties (Table 3). Flag leaf area of Shatabdi, Bijoy and Prodip were 17, 15 and $19 \mathrm{~cm}^{2}$, respectively under control condition. Flag leaf area Shatabdi, Bijoy and Prodip were reduced to 14.57 and 8.64 and 12.34 at $35^{\circ} \mathrm{C}$, respectively.

Table 3. Effects of temperature on flag leaf length $(\mathrm{cm})$ and area $\left(\mathrm{cm}^{2}\right)$.

\begin{tabular}{lcccccc}
\hline \multirow{2}{*}{ Cultivar } & \multicolumn{2}{c}{ Flag leaf length $(\mathrm{cm})$} & \multicolumn{3}{c}{ Flag leaf area $\left(\mathrm{cm}^{2}\right)$} \\
\cline { 2 - 7 } & Control & $28^{\circ} \mathrm{C}$ & $35^{\circ} \mathrm{C}$ & Control & $28^{\circ} \mathrm{C}$ & $35^{\circ} \mathrm{C}$ \\
\hline Shatabdi & $18.0 \pm 0.8$ & $17.75 \pm 0.7$ & $17.2 \pm 1$ & $16.92 \pm 0.2$ & $16.92 \pm 0.2$ & $16.92 \pm 0.2$ \\
Bijoy & $15.93 \pm 0.6$ & $12.970 .8 \pm$ & $11.87 \pm 1$ & $13.68 \pm 0.3$ & $13.68 \pm 0.3$ & $13.68 \pm 0.3$ \\
Prodip & $19.5 \pm 4$ & $15.93 \pm 1.7$ & $13.43 \pm 1$ & $19.0 \pm 0.3$ & $19.0 \pm 0.3$ & $19.0 \pm 0.3$ \\
\hline
\end{tabular}

Considering relative flag leaf area, Bijoy showed a $36 \%$ decrease at $35^{\circ} \mathrm{C}$ and the cultivar Shatabdi showed only $8 \%$ decrease as compared to control (Fig. 2). Similar observations were also observed in rice (Yue et al. 2006), and Oat (Peltonen-Sainio 1990).

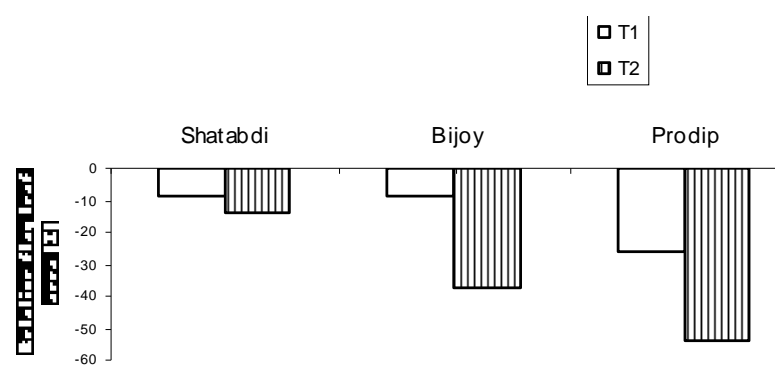

Fig. 2. Effects of temperature on relative leaf area of wheat.

In general crop growth is the measure of dry matter accumulation. Dry matter accumulation of leaf increased up to 70 days after sowing (DAS) under control condition $\left(25^{\circ} \mathrm{C}\right)$ (Table 4$)$.

Table 4. Effects of temperatures on leaf dry weight of wheat.

\begin{tabular}{|c|c|c|c|c|c|c|c|c|c|}
\hline \multirow{2}{*}{$\begin{array}{l}\text { Days after } \\
\text { sowing }\end{array}$} & \multicolumn{3}{|c|}{ Shatabdi } & \multicolumn{3}{|c|}{ Bijoy } & \multicolumn{3}{|c|}{ Prodip } \\
\hline & Optimum & $28^{\circ} \mathrm{C}$ & $35^{\circ} \mathrm{C}$ & Optimum & $28^{\circ} \mathrm{C}$ & $35^{\circ} \mathrm{C}$ & Optimum & $28^{\circ} \mathrm{C}$ & $35^{\circ} \mathrm{C}$ \\
\hline 50 & $0.64 \pm .03$ & $0.36 \pm .07$ & $0.22 \pm .01$ & $0.73 \pm .1$ & $0.25 \pm 0.9$ & $0.13 \pm .03$ & $1.18 \pm .2$ & $0.46 \pm .09$ & $0.31 \pm .3$ \\
\hline 70 & $0.68 \pm .05$ & $0.30 \pm .1$ & $0.19 \pm .03$ & $0.80 \pm .2$ & $0.24 \pm .04$ & $0.19 \pm .03$ & $2.22 \pm .04$ & $0.38 \pm .1$ & $0.12 \pm .03$ \\
\hline
\end{tabular}

Shatabdi showed better performance than Bijoy and Prodip when grown at $28^{\circ} \mathrm{C}$ but dry matter of leaf was severely affected at higher temperature $\left(35^{\circ} \mathrm{C}\right)$. A reduction in leaf area and leaf dry weight at high temperature was also observed by Campbell and Read (1968). The highest stem dry weight (2.87) was observed in Shatabdi at harvest when 
grown under control condition. Stem dry weight of Shatabdi reduced to 2.1 and 0.92 at 28 and $35^{\circ} \mathrm{C}$, respectively (Table 5).

Table 5. Effects of temperatures on stem dry weight.

\begin{tabular}{cccccccccc}
\hline \multirow{2}{*}{$\begin{array}{c}\text { Days after } \\
\text { sowing }\end{array}$} & \multicolumn{3}{c}{ Shatabdi } & \multicolumn{3}{c}{ Bijoy } & \multicolumn{3}{c}{ Prodip } \\
\cline { 2 - 10 } & Control & $28^{\circ} \mathrm{C}$ & $35^{\circ} \mathrm{C}$ & Control & $28^{\circ} \mathrm{C}$ & $35^{\circ} \mathrm{C}$ & Control & $28^{\circ} \mathrm{C}$ & $35^{\circ} \mathrm{C}$ \\
\hline 50 DAS & $2.49 \pm .5$ & $1.36 \pm .2$ & $0.75 \pm .4$ & $3.36 \pm .8$ & $1.23 \pm .4$ & $1.15 \pm .02$ & $3.73 \pm 2$ & $0.99 \pm .2$ & $1.48 \pm .5$ \\
70 DAS & $3.08 \pm .7$ & $0.83 \pm .1$ & $0.49 \pm 09$ & $3.35 \pm .2$ & $0.87 \pm .1$ & $0.89 \pm .2$ & $6.16 \pm 1$ & $1.08 \pm .1$ & $0.57 \pm .04$ \\
At harvest & $2.87 \pm .6$ & $2.1 \pm .3$ & $0.92 \pm .3$ & $2.28 \pm .4$ & $1.15 \pm .1$ & $0.81 \pm .2$ & $2.51 \pm .7$ & $1.48 \pm .1$ & $1.27 \pm .07$ \\
\hline
\end{tabular}

It is observed that among the climatic factors temperature during growth period is more influential on chlorophyll content (Jun et al. 1990). Chlorophyll a, b, as well as total chlorophyll decreased with the increase in temperature stress (Table 6). Chlorophyll content also varied among the variety. Under control condition, Bijoy showed highest chlorophyll content followed by Prodip. Leaf chlorophyll decrease under high temperature was also observed in rice flag leaf (Akter et al. 2010) and mung bean (Heart and Ormord 1979).

Table 6. Effects of temperature on chlorophyll contents.

(a) vegetative stage

\begin{tabular}{cccccccccc}
\hline & \multicolumn{8}{c}{ Chlorophyll content mg/g fresh tissue } \\
\cline { 2 - 10 } Cultivars & \multicolumn{3}{c}{ Chlorophyll, a } & \multicolumn{3}{c}{ chlorophyll, b } & \multicolumn{3}{c}{ Total chlorophyll } \\
\cline { 2 - 10 } & Control & $28^{\circ} \mathrm{C}$ & $35^{\circ} \mathrm{C}$ & Control & $28^{\circ} \mathrm{C}$ & $35^{\circ} \mathrm{C}$ & Control & $28^{\circ} \mathrm{C}$ & $35^{\circ} \mathrm{C}$ \\
\hline Shatabdi & $2.33 \pm .09$ & $2.05 \pm 0.4$ & $1.60 \pm 0.5$ & $0.80 \pm 0.1$ & $0.69 \pm .4$ & $0.63 \pm .08$ & $3.15 \pm 0.6$ & $2.82 \pm .1$ & $2.25 \pm 0.5$ \\
Bijoy & $3.03 \pm 0.2$ & $2.78 \pm .1$ & $2.62 \pm .1$ & $1.15 \pm .2$ & $0.96 \pm 05$ & $0.88 \pm .04$ & $4.23 \pm .4$ & $3.56 \pm .1$ & $3.80 \pm .6$ \\
Prodip & $2.98 \pm 2$ & $2.71 \pm .4$ & $2.55 \pm .8$ & $1.14 \pm .2$ & $1.04 \pm .1$ & $0.98 \pm .2$ & $4.25 \pm .5$ & $3.70 \pm .2$ & $3.41 \pm .9$ \\
\hline
\end{tabular}

(b) Booting stage

\begin{tabular}{cccccccccc}
\hline & \multicolumn{8}{c}{ Chlorophyll content mg/g fresh tissue } \\
\cline { 2 - 10 } Cultivars & \multicolumn{3}{c}{ Chlorophyll, a } & \multicolumn{3}{c}{ chlorophyll, b } & \multicolumn{3}{c}{ Total chlorophyll } \\
\cline { 2 - 10 } & Control & $28^{\circ} \mathrm{C}$ & $35^{\circ} \mathrm{C}$ & Control & $28^{\circ} \mathrm{C}$ & $35^{\circ} \mathrm{C}$ & Control & $28^{\circ} \mathrm{C}$ & $35^{\circ} \mathrm{C}$ \\
\hline Shatabdi & $3.81 \pm .3$ & $2.94 \pm .1$ & $2.24 \pm .08$ & $1.10 \pm 0.8$ & $.84 \pm 0.7$ & $0.66 \pm 0.5$ & $4.91 \pm 0.4$ & $3.75 \pm 0.1$ & $2.95 \pm 0.9$ \\
Bijoy & $3.70 \pm 0.1$ & $2.84 \pm .4$ & $2.33 \pm .4$ & $1.03 \pm .03$ & $0.73 \pm .07$ & $0.64 \pm .1$ & $4.70 \pm .1$ & $3.42 \pm .4$ & $2.97 \pm .4$ \\
Prodip & $3.07 \pm .2$ & $2.85 \pm .2$ & $2.41 \pm .06$ & $0.77 \pm .08$ & $0.71 \pm .07$ & $0.62 \pm 0.8$ & $3.87 \pm .3$ & $3.58 \pm .3$ & $2.97 \pm 01$ \\
\hline
\end{tabular}

(c) Anthesis stage

\begin{tabular}{cccccccccc}
\hline & \multicolumn{9}{c}{ Chlorophyll content mg/g fresh tissue } \\
\cline { 2 - 10 } Cultivars & \multicolumn{3}{c}{ Chlorophyll, a } & \multicolumn{3}{c}{ chlorophyll, b } & \multicolumn{3}{c}{ Total chlorophyll } \\
\cline { 2 - 10 } & Control & $28^{\circ} \mathrm{C}$ & $35^{\circ} \mathrm{C}$ & Control & $28^{\circ} \mathrm{C}$ & $35^{\circ} \mathrm{C}$ & Control & $28^{\circ} \mathrm{C}$ & $35^{\circ} \mathrm{C}$ \\
\hline Shatabdi & $3.56 \pm .08$ & $2.78 \pm .3$ & $1.96 \pm .3$ & $1.30 \pm .1$ & $0.98 \pm .03$ & $0.94 \pm .05$ & $2.44 \pm .06$ & $1.89 \pm .3$ & $1.85 \pm .1$ \\
Bijoy & $2.95 \pm .2$ & $2.56 \pm .4$ & $1.46 \pm .1$ & $0.99 \pm .03$ & $0.99 \pm .01$ & $0.71 \pm .05$ & $2.03 \pm .1$ & $1.76 \pm .2$ & $1.02 \pm .2$ \\
Prodip & $3.07 \pm .1$ & $2.68 \pm .4$ & $1.96 \pm .3$ & $1.0 \pm .02$ & $0.83 \pm .05$ & $0.67 \pm .1$ & $2.10 \pm .07$ & $1.97 \pm .2$ & $1.30 \pm .2$ \\
\hline
\end{tabular}

At $28^{\circ} \mathrm{C}$, Shatabdi showed the highest relative total chlorophyll content (90\%) at vegetative stage but at $35^{\circ} \mathrm{C}$ it (Shatabdi) showed the lowest relative chlorophyll content 
(Fig. 4) as compared to control. Heart and Ormord 1979, observed decrease in chlorophyll content with the increase in temperature.

Grain yield and yield contributing characters studied were significantly influenced by temperature. Temperature imposed by delayed sowing cause higher grain yield reduction of wheat as observed by Verma et al. (1987).

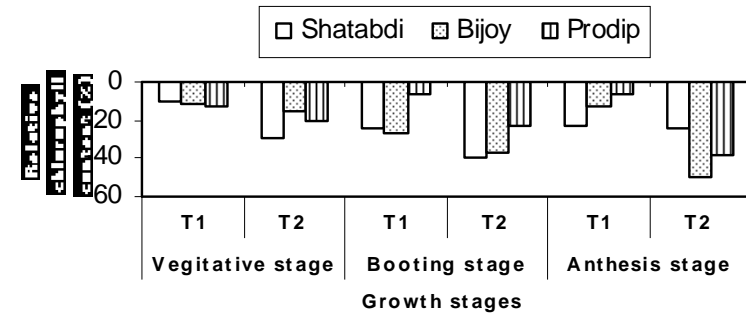

Fig. 3. Effects of temperature on relative total chlorophyll content at different growth stages of wheat.

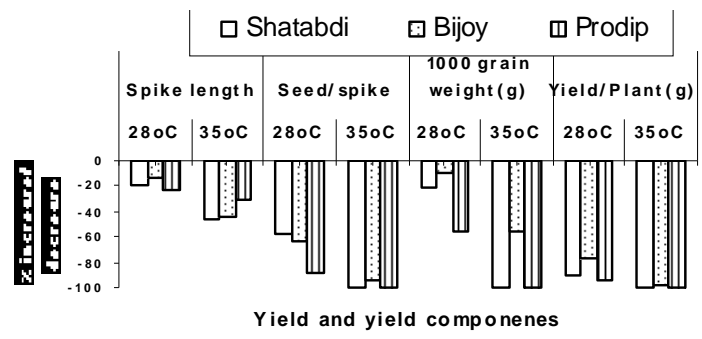

Fig. 4. Effects of temperature on relative yield and yield contributing characters of wheat.

Yield contributory characters like spike length, number of spikelet per spike, number of seed per spike and 1000 -grain weight were reduced at $28^{\circ} \mathrm{C}$ in Shatabdi, Bijoy and Prodip (Table 7). Maximum reduction in spike length (-23\%) was obserbed in the variety Prodip at $28^{\circ} \mathrm{C}$. At $35^{\circ} \mathrm{C}$, the maximum reduction was observed in shatabdi $(-46 \%)$ which is closely followed by Bijoy $(-45 \%)$. A $31 \%$ reduction was observed in case of prodip at $35^{\circ} \mathrm{C}$. Number of grains per spike varied among the varieties (35 to 43 nos.). At $28^{\circ} \mathrm{C}$ the number of seeds decreased and it varied from 5 to 16 . A decrease in number of grains per ear was also observed in Barley (Kim et al. 1985, Raw and Wattal 1986).

The 1000-grain weight was highest in Bijoy (55.4 gm) followed by Prodip (49.8 gm) and Shatabdi (43.8 g) under control condition but it reduced to 34.6, 50.0 and $49.0 \mathrm{~g}$ in Shatabdi, Bijoy and Prodip, respectively at $28^{\circ} \mathrm{C}$ (Table 7). At $28^{\circ} \mathrm{C}$, Bijoy performed better when 1000 -grain weight is considered. Only a $10 \%$ decrease in 1000-grain weight was observed in case of Bijoy at $28^{\circ} \mathrm{C}$ and it reduced to $55 \%$ when wheat plant was grown at $35^{\circ} \mathrm{C}$. In case of Shatabdi and Prodip 1000-grain weight decreased by 90 and $95 \%$ at $28^{\circ} \mathrm{C}$, respectively. Both the varieties failed to produce any seed at higher temperature like $35^{\circ} \mathrm{C}$ as the florets become sterile. At high temperature failure of grain set and lost florets were observed by Zing et al. 
(1985). Rawson et al. 1978) also observed floret sterility of wheat at higher temperature. A decrease in grain dry weight was also reported by Shukla et al. (1998). A reduction in grain number was also observed in semi dwarf wheat (Tashiro and Wardlow 1990). When wheat plants were grown at $35^{\circ} \mathrm{C}$ all the varieties failed to form any seed (Table 7). The failure of grain set under higher temperature may be due to floret sterility as observed by Rawson (1986). Maturity of seed is influenced by the high temperature which resulted in loss of seed weight as observed in phlox (Kumar and Kaur 2000). Temperature also reduced the grain yield of barley by reducing number of grains/ear (Austin 1980).

Table 7. Effects of temperatures on yield and yield contributing characters of wheat.

\begin{tabular}{lllllll}
\hline Cultivars & $\begin{array}{l}\text { Treatment } \\
{ }^{\circ} \mathrm{C}\end{array}$ & $\begin{array}{c}\text { Spike } \\
\text { length }(\mathrm{cm})\end{array}$ & $\begin{array}{c}\text { Spikelet/spike } \\
(\text { no. })\end{array}$ & $\begin{array}{c}\text { Seed/spike } \\
\text { (no. })\end{array}$ & $\begin{array}{l}\text { 1000-grain } \\
\text { weight }(\mathrm{g})\end{array}$ & $\begin{array}{c}\text { Yield/ } \\
\text { plant }(\mathrm{g})\end{array}$ \\
\hline Shatabdi & Control & $14.85 \pm 0.3$ & $14.1 \pm 0.2$ & $38.3 \pm 1.0$ & $43.8 \pm 0.5$ & $2.32 \pm 0.7$ \\
& 28 & $11.88 \pm 0.6$ & $12.13 \pm 0.7$ & $16 \pm 0.5$ & $34.6 \pm 0.4$ & $0.25 \pm .01$ \\
& 35 & $8.0 \pm 0.5$ & $7 \pm 0.7$ & 0 & 0 & 0 \\
Bijoy & Control & $14.05 \pm 0.5$ & $14.1 \pm 0.6$ & $35 \pm 2.0$ & $55.4 \pm 0.2$ & $2.23 \pm 0.7$ \\
& 28 & $12.25 \pm 0.4$ & $12.7 \pm 0.3$ & $13 \pm 2.0$ & $50.0 \pm 0.5$ & $0.53 \pm .05$ \\
& 35 & $7.75 \pm 0.5$ & $7 \pm 0.7$ & 2 & 0 & $0.05 \pm$ \\
Prodip & Control & $15.5 \pm 0.3$ & $17.0 \pm 0.5$ & $43.0 \pm 2.0$ & $4.90 \pm .04$ & $2.35 \pm 0.5$ \\
& 28 & 12.0 & 11.2 & $5 \pm 1$ & 0 & $0.11 \pm .03$ \\
& 35 & $10.7 \pm 0.5$ & $10.4 \pm 1.0$ & 0 & 0 & 0 \\
\hline
\end{tabular}

The experiment revealed that total crop duration i.e., sowing to maturity reduced at $28^{\circ} \mathrm{C}$ and also at $35^{\circ} \mathrm{C}$. The high temperature also shortens the developmental phase. Higher grain weight was observed to be associated with longer grain filling period as reported by other workers. Flag leaf area of wheat responsible for supplying photosynthetic product for grain growth reduced under higher temperature stress. Another negative effect of temperature on yield was through the reduction of chlorophyll content due to high temperature. Higher temperature fastens the age of flag leaf and enhanced senescence as rate of chlorophyll degradation was accelerated under higher temperature. Also high temperature brought about floret sterility and consequently negatively affected the grain development and ultimately effect yield reduction in wheat. Higher temperature is not only reducing the size of the grains but also reduce its number as high temperature causes sterility in florets. The yield decrease, was due to reduction in the number (Table 7) of seeds per spike and also due to reduction in seed size as well as 1000-grain weight.

\section{REFERENCES}

Akter, J., M.M. Haque, A. Hamid and K.M.S. Haque. 2010, Elevated $\mathrm{CO}_{2}$ and high temperature effects on photosynthesis, growth and productivity of some indigenous rice cultivars of Bangladesh. Bangladesh Agron. J. 13(1 and 2): 1-11.

Austin, R. B., C.L. Morgan, M. A. Frod and R. B. Blackwell. 1980. Contribution to grain yield from pre-anthesis assimilation in tall and dwarf barley phenotypes in two contrasting season. Ann. Bot. 45: 309-319. 
Campbell, C.A. and D.W.L. Read. 1968. Influence of air temperature, high intensity and soil moisture on the growth, yield and some growth analysis characteristics of wheat grown in the growth chamber. Can. J. Plant Sci. 48: 299-311.

Gardner, F. P., R. B. Pearceand and R. L. Mitchell. 1985. Physiology of crop plants. Iowa state Univ. Press, Anes, Iowa, USA.

Hearth, H. M. W. and D.P. Ormrod. 1979. Effects of temperature and photoperiod on winged beans (phosphocarpus tetragenolobue L. (D.C) Ann. Bot. 43: 729-736.

Jun, C.J. and M.Sooich, 1990. The propanil hydrolyzing enzyme aryl acylamidase in the wild races of genus Oryza. Biochem. Physiol. 38: 26-33.

Kim, T.S., N.H.Cho, S.K. Park, J.H. Lee and D.U. Chooi.1985. Effect of sowing dates on growth and yield of Barley. Research Report of Rural Development Administration. Crops 27: 129-138

Kumar, R. and K. Kaur. 2000. Effect of planting time and cultivars on growth flowering and seed yield in phlox (Phlox drumondii). Seed Res. 28 (1): 23-26.

Mishra, V., R. D. Mishra, Mohendra Sing and R. S. Verma. 2003. Dry matter accumulation at preand post anthesis and yield of wheat (Tritium aestivum as affected by temperature stress and genotypes. Indian J. Agron. 48(4): 27-281.

Peltonen -Sainio. 1990. Genetic improvements in the structure of oat stands in northern growing conditions during this century. Plant Breed. 104: 340-345.

Rao, S. and P.N. Wattal. 1986. Effect of different dates of sowing on yield and yield attributes of barley genotypes. Indian J. Plant Physiol. 29: 297-301.

Rawson, H.M. 1986. High temperature tolerant wheat. A description of variation and a search for some limitation to productivity. Field Crop. Res. 14: 197-212.

Roy, S. K. and E. D. Nafgizer. 1987. Effect of sowing date on yield and yield attributes of three varieties of Barley. Bangladesh Agron. J. 2 (1): 64-67.

Siman M.R. 1999. Inheritance of flag leaf angle, flag leaf area and flag angle, leaf area duration in four Wheat crosser. Theor. Appl. Genet. 98(2): 310-314.

Tandon, J. P. 1984. Wheat improvement programm for the hotter parts of India. In: Wheats for mean tropical environments. Proceedings of the International symposium. September24-28. Mexico, D. F. Sponsored by UNDP and CIMMYT. pp. 63-67.

Tashiro, T. and I. F.Wardlow. 1990. The effect of high temperature at different stages of ripening on grain set, grain weight and grain dimensions in the semi-dwarf wheat banks. Ann. Bot. 65(1): 151-61

Verma U. K., B. N. Verma and S. P. Sing. 1978. Effects of time of sowing on the performance of five high yielding wheat varieties. Field Crop Abstract 33 (6): 412

Wang, Y.P. Jr., Handoko and G.M.Rimmington. 1992. Sensitivity of Wheat growth to increased air temperature for different scenaries of ambient $\mathrm{CO}_{2}$ concentration and rainfall in Victoria- a simulation study. Climate Res. 2: 131149.

Witham, F.A., D.E. Blaydes and R. M. Devlin. 1971. Chlorophyll absorption spectrum and quantitative determination. In: Experiments in Plant Physiology. Pub. by Van Nastrated Reinhold comp. New York. pp. 55-56.

Yue B., W. Xue, Luo L. and Y. Xing. 2006. QTL analysis for flag leaf characteristics and their relationships with yield and yield traits in rice. Acta Genet. Sin. 33(9): 824-832.

Zing, Z.R., J. M. Margan and R.W. King. 1985. Regulation of grain number in wheat genotypic difference and responses to applied abscisic acid and to high temperature. Aust. J. Plant Physiol. 21: 609-619. 